\title{
PENINGKATAN HASIL BELAJAR POLITIK LUAR NEGERI INDONESIA MELALUI MODEL KEBERSTRU
}

\author{
Burhanudin \\ e-mail : burhanudinkza@gmail.com
}

\begin{abstract}
Abstrak: Mata pelajaran Pendidikan Kewarganegaraan membekali siswa dengan kemampuan sosial, cermat dan sistematis. Hasil observasi yang dilakukan di siswa kelas VI SDN Bantaran I diketahui bahwa terdapat permasalahan pada pembelajaran Pendidikan Kewarganegaraan sebagai berikut. (1) hasil belajar siswa kelas VI masih berada di bawah KKM yang ditentukan yaitu 70, hal ini dapat dilihat dari 30 siswa terdapat 14 siswa atau $48 \%$ siswa tidak tuntas dan lambat dalam belajar, (2) rendahnya tingkat keaktifan dan sikap kerjasama antar siswa selama proses pembelajaran, (3) guru tidak menggunakan media pembelajaran yang sesuai dengan materi, sehingga siswa mengalami kesulitan dalam memahami materi, (4) guru selama proses pembelajaran menggunakan model pembelajaran konvensional, sehingga pembelajaran terpusat oleh guru. Untuk memperbaiki keadaan tersebut dilakukan Penelitian Tindakan Kelas (PTK). Rumusan masalah pada penelitian ini sebagai berikut. (1) bagaimanakah penerapan model Keberstu (Kepala Bernomor Struktur) pada materi Politik Luar Negeri Indonesia di Kelas VI SDN Bantaran I, (2) apakah ada peningkatan hasil belajar pada materi Politik Luar Negeri Indonesia setelah menerapkan model Keberstu (Kepala Bernomor Struktur) di Kelas VI SDN Bantaran I Kecamatan Bantaran.Penelitian ini merupakan Penelitian Tindakan Kelas (PTK) dengan pendekatan deskriptif kualitatif yang dilakukan secara kolaboratif antara peneliti dan guru kelas $V$, sehingga dapat memperbaiki kinerja guru dan hasil belajar siswa meningkat. Prosedur PTK terdiri dari dua siklus, masing-masing siklus menggunakan langkah-langkah sebagai berikut. (1) perencanaan, (2) tindakan, (3) pengamatan, (4) refleksi. Subjek penelitian yaitu peneliti yang bertindak sebagai guru yang mengajar siswa kelas VI SDN Bantaran I Kecamatan Bantaran Kabupaten Probolinggo yang berjumlah 30 siswa.Hasil penelitian menunjukkan bahwa persentase aktivitas guru dalam penerapan pelaksanaan pembelajaran pada siklus I pertemuan I sebesar 78\%, siklus I pertemuan II sebesar $84 \%$, siklus II pertemuan I sebesar 94\%, dan siklus II pertemuan II sebesar 100\%. Untuk persentase hasil belajar siswa pada siklus I pertemuan I sebesar 75,93\%, siklus I pertemuan II sebesar 78,63\%, siklus II pertemuan I sebesar 90,30\%, dan siklus II pertemuan II sebesar 93,00\%.Berdasarkan hasil penelitian tersebut dapat disimpulkan bahwa penerapan model Keberstu (Kepala Bernomor Struktur) dapat meningkatkan aktivitas guru dalam proses pembelajaran dan hasil belajar siswa kelas VI SDN Bantaran I Kecamatan Bantaran Kabupaten Probolinggo.
\end{abstract}

Kata kunci: model keberstru, hasil belajar, politik luar negeri Indonesia

Politik Luar Negeri Indonesia merupakan salah satu standar kompetensi pada mata pelajaran Pendidikan Kewarganegaraan yang diberikan pada kelas VI. Dalam kompetensi ini dipelajari tentang politik luar negeri yang wajib dipahami 
dan dikuasai oleh siswa kelas VI. Permasalahan yang ditemukan dalam proses pembelajaran berkaitan dengan guru maupun siswa, menunjukan hasil observasi yang dilakukan pada hari Kamis, 1 Maret 2018 di kelas VI SD Negeri Bantaran I kabupaten Probolinggo sebagai berikut : (1) hasil belajar siswa kelas VI pada materi Mengenal Lembaga Pemerintahan Provinsi masih berada di bawah Kriteria Ketuntasan Minimal (KKM) yang sudah ditentukan yaitu 70, hal ini dapat dilihat dari 30 siswa terdapat 14 siswa atau $48 \%$ siswa tidak tuntas dan lambat dalam belajar, hal tersebut menunjukkan bahwa siswa kurang memahami materi yang diajarkan. (2) rendahnya tingkat keaktifan dan sikap saling kerjasama antar siswa selama proses pembelajaran berlangsung, hal tersebut dapat dilihat dari banyaknya siswa yang hanya diam dan ramai sendiri selama proses pembelajaran berlangsung. (3) guru selama proses pembelajaran menggunakan model pembelajaran yang kurang menarik, sehingga proses pembelajaran terpusat dan lebih didominasi oleh guru. Hal ini menyebabkan siswa merasa pasif, bosan, dan jenuh dalam belajar, sehingga pesan yang terkandung dalam materi pelajaran yang telah disampaikan oleh guru kurang dapat diterima dan dipahami oleh siswa.

Permasalahan yang ada di kelas VI SD Negeri Bantaran I Kabupaten Probolinggo adanya hasil belajar peserta didik yang kurang sesuai dengan pengertian dari pendidikan. Pendidikan merupakan usaha sadar dan terencana untuk mewujudkan suasana belajar dan proses pembelajaran agar siswa secara aktif mengembangkan potensi yang ada di dalam dirinya. Untuk dapat mengembangkan potensi yang ada di dalam diri siswa, maka perlu adanya perbaikan dalam proses pembelajaran. "Kualitas dan keberhasilan pembelajaran sangat dipengaruhi oleh ketepatan dalam memilih dan mengembangkan model serta metode pembelajaran" (Budiyanto, 2004:345). Pemakaian model pembelajaran harus dilandaskan pada pertimbangan untuk menempatkan siswa sebagai subjek belajar yang tidak hanya menjadikan siswa pasif saat belajar di dalam kelas, namun guru harus dapat menempatkan siswa sebagai insan yang memiliki pengalaman, keinginan, kemauan, dan pikiran yang dapat dimanfaatkan untuk belajar, baik secara individu maupun secara kelompok di dalam kelas. Oleh karena itu peneliti mengembangkan model diskusi untuk menyelesaikan 
permasalahan yang ada melalui penerapan model KEBERSTRU (Kepala Bernomor Struktur).

Alasan penerapan model KEBERSTRU ( Kepala Bernomor Struktur) pada siswa kelas VI di SD Negeri Bantaran I Kabupaten Probolinggo, sebagai berikut. (1) dengan menggunakan model KEBERSTRU (Kepala Bernomor Struktur) dapat mengurangi kelambatan belajar siswa dan meningkatkan hasil belajar siswa, karena model ini memberikan kesempatan kepada siswa agar dapat terlibat secara langsung dan aktif selama proses pembelajaran berlangsung, sehingga siswa dapat mengembangkan keterampilan mengamati, menanya, menalar, mencoba, dan mengkomunikasikan dengan baik; (2) dengan menggunakan model KEBERSTRU (Kepala Bernomor Struktur) rendahnya tingkat keaktifan dan sikap saling kerjasama antar siswa dapat ditingkatkan karena model ini menerapkan sikap saling berinteraksi antara siswa dalam kelompok dengan cara siswa yang pandai dapat mengajari siswa yang kurang pandai; (3) dengan menggunakan model KEBERSTRU (Kepala Bernomor Struktur) dominasi guru dalam proses pembelajaran dapat dikurangi karena model ini memberikan kesempatan kepada siswa untuk berfikir kritis dan membangun pengetahuannya sendiri, sehingga guru hanya berperan sebagai fasilitator dan motivator. Gultom (2004) berpendapat bahwa penerapan model kepala bernomor struktur dapat lebih mengaktifkan siswa di kelas dan senantiasa mempersiapkan diri menghadapi kompetensi dengan belajar terlebih dahulu serta dapat mengaktifkan interaksi teman dalam kelompoknya. Sehingga proses pembelajaran akan lebih hidup, bermakna, dan menyenangkan.

Tujuan penelitian ini dapat penulis uraikan, adalah bahwa mendeskripsikan penerapan model KEBERSTRU (Kepala Bernomor Struktur) pada materi Politik Luar Negeri Indonesia di kelas VI SD Negeri Bantaran I kecamatan Bantaran Kabupaten Probolinggo, serta untuk mendeskripsikan peningkatan hasil belajar siswa kelas VI di SD Negeri Bantaran I kecamatan Bantaran Kabupaten Probolinggo dengan penerapan model pembelajaran KEBERSTRU.

\section{Hasil Belajar}


Hasil belajar adalah perubahan yang mengakibatkan manusia berubah dalam sikap dan tingkah lakunya. Menurut Sudjana (2005:10) hasil belajar adalah suatu hasil belajar secara komperhensif meliputi bidang kognitif, afektif, dan psikomotor. Hasil belajar siswa dapat diukur melalui evaluasi. Menurut Dimyati dan Mudjiono (2006:200) menyatakan bahwa evaluasi hasil belajar merupakan proses untuk menentukan nilai belajar siswa melalui kegiatan penilaian dan pengukuran hasil belajar. Tujuan utama evaluasi belajar adalah untuk mengetahui tingkat keberhasilan yang telah dicapai oleh siswa setelah mengikuti suatu pembelajaran, dimana tingkat keberhasilan tersebut kemudian ditandai dengan skala nilai atau huruf. Hasil evaluasi dapat digunakan oleh guru untuk memberikan laporan secara rutin tentang hasil belajar siswa kepada wali murid sebagai pertanggungjawaban yang dituangkan dalam buku rapor. Nilai hasil belajar siswa yang tertuang dalam buku rapor tersebut dapat memberikan gambaran tentang hasil belajar siswa yang dicapainya dalam suatu segi pendidikan dalam jangka waktu tertentu, selain itu juga dapat menggolongkan tingkat kemampuan siswa dalam mengikuti proses belajar mengajar di sekolah.

\section{Politik Luar Negeri Indonesia}

Pengertian Pendidikan Kewarganegaraan menurut Peraturan Menteri Pendidikan Nasional Nomor 22 Tahun 2006 tentang Standar Isi untuk Satuan Pendidikan Dasar dan Menengah adalah mata pelajaran yang memfokuskan pada pembentukan warga negara yang memahami dan mampu melaksanakan hak-hak dan kewajibannya untuk menjadi warga negara Indonesia yang cerdas, terampil, dan berkarakter yang diamanatkan oleh Pancasila dan UUD 1945.

Politik luar negeri diartikan sebagai polaperilaku yang diwujudkan suatu negara sewaktu mewujudkan kepentingannyadalam hubungannya dengan negara lain (Warsito Adnan, 2012). Hubungan antara negara satu dengan lainnya wajib saling menghormati, bekerjasama secara adil dan damaiuntuk mewujudkan kerukunan hidup antar negara. Politik atau kebijakan luar negeri suata negara berbeda dengan negara lain. Hal ini disebabkan faktor-faktor yang turut mempengaruhi corak politik luar negeri yang dijalankan negara yang 
bersamgkutan. Perbedaan politik suatu negara ini salah satunya disebabkan oleh idelogi yang dianut oleh masing-masing negara.

Sebagai negara yang merdeka dan berdaulat serta sebagai anggota masyarakat internasional, negara Indonesia juga mempunyai politik luar negeri. Politik luar negeri Indonesia diabadikan untuk kepentingan nasional sebagai langkah dalam mendukung terwujudnya tujuan negara sebagaimana yang tersebut di dalam pembukaan UUD 1945.

\section{Model Keberstru (Kepala Bernomor Struktur )}

Model pembelajaran KEBERSTRU dirancang sebagai variasi diskusi kelompok yang lebih mengedepankan kepada aktivitas siswa dalam mengamati, menanya, menalar, mencoba, dan mengkomunikasikan jawaban dari pertanyaan atau soal yang diberikan oleh guru, sehingga siswa dapat membangun pengetahuannya sendiri dan terlibat secara aktif dalam proses pembelajaran. Selain itu, model ini juga mendorong siswa untuk meningkatkan semangat kerjasama dalam kelompok. Model Pembelajaran_Kepala Bernomor Struktur merupakan modifikasi dari model pembelajaran Numbered Heads Together. Perbedaan yang mendasar antara keduanya adalah pada penugasan dan masuk keluarnya anggota kelompok. Pada pembelajaran kepala bernomor struktur ini, siswa dikelompokkan dengan diberi nomor dan setiap nomor mendapat tugas berbeda dan nantinya dapat bergabung dengan kelompok lain yang bernomor sama untuk bekerjasama.

Ciri khas dari model KEBERSTRU (Kepala Bernomor Struktur) adalah masing-masing siswa dalam satu kelompok memperoleh nomor yang berbeda, setiap siswa dalam satu kelompok harus saling bekerjasama dan berfikir aktif untuk menyelesaikan soal atau pertanyaan yang diberikan oleh guru. Setelah siswa selesai menjawab pertanyaan atau soal yang diberikan oleh guru, siswa diberi kesempatan untuk bergabung dengan nomor yang sama untuk saling bekerjasama. Setelah selesai berdiskusi dan menjawab pertanyaan, guru menunjuk salah seorang siswa yang mewakili kelompoknya, tanpa memberi tahu terlebih dahulu siapa yang akan mewakili kelompoknya. Hal ini dilakukan sesuai dengan tujuan 
dari model KEBERSTRU (Kepala Bernomor Struktur) menurut Nur Muhammad (2005:78) yaitu, adanya keterlibatan total semua siswa dan meningkatkan tanggung jawab individu dalam diskusi kelompok.

\section{Methode Penelitian}

Penelitian ini menggunakan pendekatan deskriptif kualitatif dengan cara mendeskripsikan peristiwa-peristiwa sebagaimana terjadi secara alami, melalui pengumpulan data dengan instrumen kunci peneliti sendiri. Penelitian ini menggunakan jenis Penelitian Tindakan Kelas (PTK) sesuai dengan pendapat Arikunto, (2005:24).yang menyatakan bahwa Penelitian Tindakan Kelas (PTK) adalah penelitian tindakan yang dilakukan dengan tujuan untuk memperbaiki mutu praktek pembelajaran di dalam kelas. Menurut Kemmis dan Mc Taggart (dalam Sa'dun, 2009:27) Penelitian Tindakan Kelas (PTK) terdiri dari 4 (empat) komponen pokok, meliputi: (1) perencanaan (planning), (2) tindakan (acting), (3) pengamatan (observing), (4) refleksi (reflecting). Berikut uraian dari masingmasing komponen pokok.

Cara yang digunakan oleh peneliti dalam mengumpulkan data melalui Teknik Tes, observasi dan dokumentasi. Teknik tes cara mengumpulkan hasil penelitian menggunakan lembar kerja kelompok dan tes akhir dengan materi politik luar negeri Indonesia. Soal tersebut diberikan kepada siswa kelas VI ketika selesai pemberian tindakan pada setiap siklus. Hasil tes ini digunakan untuk mengetahui sejauh mana pemahaman dan keberhasilan siswa tentang materi Politik Luar Negeri Indonesia dengan menggunakan model KEBERSTRU (Kepala Bernomor Struktur). Alat yang digunakan dalam mengumpulkan data berupa instrument penilaian kognitif dan afektif. Kedua instrument tersebut digunakan untuk mengetahui tingkat keberhasilan siswa tentang materi Politik Luar Negeri Indonesia yang telah di ajarkan oleh guru. Kegiatan observasi dengan cara yang digunakan peneliti dalam mengumpulan data melalui pengamatan selama proses pembelajaran berlangsung dengan menggunakan alat berupa instrument observasi aktivitas siswa dan guru kelas VI serta diperkuat dengan menggunakan catatan lapangan dilakukan dalam rangka menilai aspek 
sikap dan psikomotor siswa selam proses kegiatan pembelajran. Dokumentasi dengan cara pengambilan gambar serta dokumen kegiatan berupa pengumpulan bukti yang terkait dengan penelitian. Teknik dokumentasi berupa kegiatan yang berfungsi sebagai alat untuk mengumpulkan bukti yang terkait dengan penelitian seperti foto persiklus. Cara yang digunakan oleh peneliti dalam mengumpulkan data dengan memotret peristiwa yang terjadi selama proses pembelajaran berlangsung dengan menggunakan kamera digital

Penelitian ini menggunakan analisis data deskriptif kualitatif. Analisis ini bersifat menggambarkan kenyataan atau fakta sesuai dengan data yang diperoleh dengan tujuan untuk mengetahui peningkatan hasil belajar siswa kelas VI pada materi politik luar negeri Indonesia. Langkah-langkah analisis data yang digunakan dalam penelitian ini sesuai dengan pendapat Sugiyono (2010: 247) menyatakan langkah-langkah analisis terdiri dari tiga alur kegiatan yang terjadi secara bersamaan, meliputi: (1) reduksi data, (2) pengajuan penyajian data, (3) penarikan kesimpulan.

Kriteria Ketuntasan Minimal (KKM) mata pelajaran Pendidikan Kewarganegaraan pada kelas VI di SD Negeri Bantaran I kabupaten Probolinggo sebesar 70. Sehingga tindakan peneliti setelah melaksanakan pembelajaran mata pelajaran Pendidikan Kewarganegaraan dengan materi Politik Luar Negeri Indonesia dapat dikatakan berhasil apabila hasil belajar siswa mendapatkan nilai minimal 70 atau lebih dari 70. Nilai akhir siswa diperoleh dari nilai lembar kerja kelompok, nilai tes akhir, nilai afektif. Pencarian nilai akhir siswa diperoleh dengan rumus sebagai berikut.

$$
\mathrm{NA}=\frac{N \cdot L K K+N \cdot T A+N \cdot A}{3}
$$

Keterangan:

NA : Nilai Akhir Siswa

N.LKK : Nilai Lembar kerja kelompok

N.TA : Nilai Tes Akhir

N.A : Nilai Afektif 
Ketuntasan klasikal dikatakan tuntas jika siswa dalam satu kelas mendapat nilai minimal 70 atau lebih dari 70 sebesar $85 \%$. Hal tersebut sesuai dengan pendapat dari Triono (2010: 241) menyatakan keberhasilan klasikal dikatakan berhasil apabila nilai siswa secara klasikal memenuhi standar yang ditentukan yaitu sebesar $\geq 85 \%$. Rumus perhitungan persentase ketuntasan belajar klasikal sebagai berikut :

Ketuntasan belajar klasikal $=\frac{\sum \text { Siswa yang tuntas }}{\sum \text { Siswa satu kelas }} \times 100 \%$

Tahap selanjutnya yang dilakukan peneliti setelah menganalisis data adalah evaluasi. Pada tahap evaluasi, peneliti mengevaluasi dari data yang sudah diperoleh untuk mengetahui perkembangan penelitian yang telah dilakukan. Setelah tahap evaluasi, peneliti melakukan refleksi terhadap data yang diperoleh dari tahap evaluasi. Hal yang dilakukan pada tahap refleksi adalah memperbaiki kekurangan yang terjadi selama proses pembelajaran untuk dilaksanakan pada tindakan selanjutnya

\section{Hasil dan Pembahasan}

Hasil observasi yang dilakukan selama pembelajaran pada siklus I ditemukan hal-hal sebagai berikut. Ada beberapa siswa yang masih merasa malu dan takut untuk mengajukan dan menjawab pertanyaan. Pada saat proses diskusi ditemukan beberapa siswa yang hanya diam saja atau tidak ikut berpartisipasi dalam diskusi. Jumlah skor yang diperoleh dari aktivitas siswa selama proses pembelajaran pada siklus I pertemuan I sebanyak 2371 dengan persentase keberhasilan 79,03\% dan kriteria keberhasilan yang diperoleh adalah baik. Mengalami peningkatan pada pertemuan II dengan memperoleh jumlah skor sebanyak 2456 dengan persentase keberhasilan 81,67\% dan kriteria keberhasilan yang diperoleh adalah baik. Jumlah skor yang diperoleh dari aktivitas guru selama proses pembelajaran pada siklus I pertemuan I sebanyak 25 dengan persentase keberhasilan $78 \%$ dan kriteria keberhasilan yang diperoleh adalah baik. 
Mengalami peningkatan pada pertemuan II dengan memperoleh jumlah skor sebanyak 27 dengan persentase keberhasilan 84\% dan kriteria keberhasilan yang diperoleh adalah baik. Jumlah skor yang diperoleh dari hasil belajar siswa pada siklus I pertemuan I sebanyak 2281 dengan persentase keberhasilan 76,04\% dan kriteria keberhasilan yang diperoleh adalah baik. Mengalami peningkatan pada pertemuan II dengan memperoleh jumlah skor sebanyak 2359 dengan persentase keberhasilan 78,63\% dan kriteria keberhasilan yang diperoleh adalah baik.Pada siklus I terdapat beberapa siswa yang nilai hasil belajar masih berada di bawah KKM dan masih dinyatakan belum tuntas.

Hasil observasi yang dilakukan selama pembelajaran pada siklus II ditemukan hal-hal sebagai berikut. Dengan melakukan pembagian anggota kelompok secara merata (menempatkan siswa yang pandai pada masing-masing kelompok) menjadikan diskusi kelompok lebih efektif karena siswa yang pandai dapat mengajari siswa yang kurang pandai. Jumlah skor yang diperoleh dari aktivitas siswa selama proses pembelajaran pada siklus II pertemuan I sebanyak 2643 dengan persentase keberhasilan 88,10\% dan kriteria keberhasilan yang diperoleh adalah sangat baik. Mengalami peningkatan pada pertemuan II dengan memperoleh jumlah skor sebanyak 2711 dengan persentase keberhasilan 90,37\% dan kriteria keberhasilan yang diperoleh adalah sangat baik. Jumlah skor yang diperoleh dari aktivitas guru selama proses pembelajaran pada siklus II pertemuan I sebanyak 30 dengan prosentase $94 \%$ dan jumlah skor pada siklus II pertemuan II sebanyak 32 dengan persentase keberhasilan 100\% dan kriteria keberhasilan yang diperoleh adalah sangat baik. Jumlah skor yang diperoleh dari hasil belajar siswa pada siklus II pertemuan I sebanyak 2709 dengan persentase keberhasilan 90,30\% dan kriteria keberhasilan yang diperoleh adalah sangat baik. Mengalami peningkatan pada pertemuan II dengan memperoleh jumlah skor sebanyak 2770 dengan persentase keberhasilan 92,93\% dan kriteria keberhasilan yang diperoleh adalah sangat baik. Nilai tersebut telah melebihi KKM yang sudah ditentukan dan siswa telah dinyatakan tuntas. 
Berdasarkan hasil temuan pada siklus I dan siklus II dapat dijabarkan temuan lengkap selama pembelajaran sebagai berikut. Proses kegiatan belajar siswa mengalami peningkatan pada setiap siklus. Pada pratindakan siswa hanya mencatat dan mendengarkan guru, akan tetapi selama pembelajaran Politik Luar Negeri Indonesia dengan menggunakan model KEBERSTRU siswa terlibat secara aktif. Hasil belajar siswa baik aspek kognitif, afektif dan psikomotorik mengalami peningkatan. Peningkatan kognitif siswa dapat dilihat dari hasil belajar siswa yang diperoleh. Peningkatan afektif siswa dapat dilihat dari sikap yang ditampilkan siswa selama pembelajaran berupa keaktifan, kerjasama, dan partisipasi siswa. Hasil wawancara dengan siswa diketahui bahwa siswa senang dengan pembelajaran yang dilakukan karena siswa menjadi lebih mengerti tentang Politik Luar Negeri Indonesia. Pembelajaran dengan melibatkan siswa secara langsung dalam menyelesaikan masalah dapat meningkatkan pemahaman siswa mengenai suatu konsep. Hal ini disebabkan karena siswa bisa mendapatkan pengalaman belajar secara langsung sehingga mereka mengalami pembelajaran yang bermakna.

Penerapan model KEBERSTRU materi Politik Luar Negeri Indonesia pada siswa kelas VI di SD Negeri Bantaran I kabupaten Probolinggo telah dilaksanakan sesuai dengan langkah-langkah model KEBERSTRU yang dikembangkan oleh Nurhadi (2004:66), meliputi: (1) penomoran (Numbering), (2) pengajuan pertanyaan (Questioning), (3) berpikir bersama (Heads Together), (5) berkelompok dengan nomor yang sama (Moving) (5) pemberian jawaban (Answering). Secara berurutan langkah-langkah tersebut dipaparkan sebagai berikut. Penomoran (Numbering), dalam tahap ini guru membagi siswa menjadi 6 kelompok yang masing-masing kelompok beranggotakan 5 siswa pada siklus I dan membagi siswa menjadi 7 kelompok dengan anggota 4 siswa siklus II. Kemudian guru membagikan nomor kepala kepada masing-masing siswa, sehingga dalam satu kelompok setiap siswa memiliki nomor kepala yang berbeda sesuai dengan jumlah anggota kelompok.

Pengajuan pertanyaan (Questioning), pada tahap ini siswa memberikan contoh menu seimbang yang ada di rumah sehari-hari dan melakukan tanya jawab 
dengan guru untuk mengukur sejauh mana rasa ingin tahu siswa terhadap materi Sistem Pemerintahan Pusat. Setelah itu guru memberikan penjelasan tentang materi Politik Luar Negeri Indonesia kepada siswa, hal ini dimaksudkan untuk menyiapkan dan membimbing siswa agar terlibat aktif selama pembelajaran. Hal tersebut sesuai dengan pendapat Abdul Azis (2007:31) menyatakan bahwa siswa akan belajar lebih baik jika dalam keadaan siap. Berdasarkan pendapat tersebut maka kesiapan siswa sangat dibutuhkan agar proses pembelajaran dapat berjalan dengan lancar. Setelah siswa siap kemudian guru mengajukan pertanyaan dalam bentuk lembar kerja siswa yang dibagikan kepada masing-masing kelompok.

Berpikir bersama (Heads Together), siswa berfikir bersama dengan teman satu kelompok untuk membahas atau menjawab pertanyaan yang dibagikan oleh guru. Setiap anggota kelompok berpartisipasi secara aktif untuk menyampaikan ide atau pendapat mereka, sehingga terciptalah suasana diskusi yang hidup. Setelah semua pertanyaan selesai dikerjakan atau dijawab, kemudian ketua kelompok mengkomunikasikan hasil diskusi kepada anggota kelompoknya, sehingga semua anggota kelompok mengetahui jawaban tersebut. Berkelompok dengan nomor yang sama (Moving), siswa diberi kesempatan untuk berkelompok dengan nomor yang sama untuk mendiskusikan dan mencocokkan jawaban yang yang dikerjakan.Pemberian jawaban (Answering), guru memanggil satu nomor tertentu, kemudian siswa dari kelompok dengan nomor yang sama mengangkat tangan dan menyiapkan jawaban. Kemudian guru menunjuk salah seorang siswa dengan nomor yang telah dipanggil sebelumnya untuk mengkomunikasikan atau menuliskan hasil diskusi atau jawaban kelompok kepada seluruh kelas. Ketika seorang siswa berhasil menjawab pertanyaan guru memberikan penguatan berupa motivasi. Kegiatan tersebut sesuai dengan pendapat Martinis Yamin (2003:80) menyatakan bahwa motivasi mendorong dan mengarahkan minat untuk mencapai tujuan belajar. Dari uraian diatas terlihat bahwa guru sudah menerapkan pembelajaran model KEBERSTRU.

Penerapan yang dilakukan oleh guru dalam melaksanakan pembelajaran dengan model KEBERSTRU mengalami peningkatan, hal ini dapat dilihat dari persentase keberhasilan aktivitas guru pada siklus I pertemuan I 76,04\%, 
pertemuan II 84\%, mengalami peningkatan pada siklus II pertemuan I 94\%, dan pertemuan II $100 \%$. Berdasarkan uraian di atas menunjukkan bahwa model KEBERSTRU pada pembelajaran Pendidikan Kewarganegaraan materi Politik Luar Negeri Indonesia di kelas VI SD Negeri Bantaran I kabupaten Probolinggo berhasil diterapkan sesuai dengan langkah-langkah penggunaan model KEBERSTRU.

Hasil belajar Politik Luar Negeri Indonesia melalui model KEBERSTRU pada siswa kelas VI di SD Negeri Bantaran I kabupaten Probolinggo diperoleh dari hasil penelitian melalui lembar kerja siswa, tes akhir, nilai afektif yang dilaksanakan pada siklus I dan siklus II. Hasil belajar siswa pada siklus I menunjukkan adanya peningkatan, yaitu persentase ketuntasan siswa pertemuan I mencapai $76,04 \%$ dan pertemuan II sebesar 78,63\% yang berarti meningkat $2,59 \%$. Secara umum hal tersebut belum dikatakan tuntas karena belum mencapai $85 \%$ siswa yang dinyatakan tuntas belajar. Oleh karena itu, hasil yang diperoleh pada siklus I diperbaiki pada siklus II. Siklus II menunjukkan hasil yaitu pada pertemuan I ketuntasan siswa mencapai 90,30\% dan pertemuan II mengalami peningkatan sebesar 92,93\%. Hasil ini menunjukkan bahwa model KEBERSTRU dapat digunakan untuk meningkatkan hasil belajar Politik Luar Negeri Indonesia kelas VI di SD Negeri Bantaran I kabupaten Probolinggo. Selain itu hasil penelitian ini dikuatkan oleh penelitian dari (Amrika Ely Widayani, 2012) yang menyatakan bahwa model KEBERSTRU dapat meningkatkan kerjasama dan keaktifan belajar siswa yang pada akhirnya dapat meningkatkan hasil belajar siswa.

Peningkatan hasil belajar siswa memberikan gambaran adanya perhatian dan pemahaman siswa terhadap pembelajaran. Dampak dari adanya perhatian dan pemahaman siswa terhadap pembelajaran juga ditunjukkan dengan peningkatan ketuntasan belajar secara umum. Peningkatan tersebut dapat dilihat pada tabel berikut ini : 
TABEL REKAPITULASI HASIL BELAJAR

PRATINDAKAN, SIKLUS I DAN SIKLUS II

\begin{tabular}{|c|l|c|c|c|}
\hline No & \multicolumn{1}{|c|}{ Nama siswa } & $\begin{array}{c}\text { Pra } \\
\text { tindakan }\end{array}$ & Siklus I & Siklus II \\
\hline \hline 1. & Robet Redi Jatmika & 65 & 73 & 91 \\
\hline 2. & Nur Alim & 60 & 63 & 89 \\
\hline 3. & Nurul Hiyadayatullah & 60 & 69 & 89 \\
\hline 4. & Sony Andika & 80 & 67 & 89 \\
\hline 5. & Abdul Hadi Arif & 75 & 76 & 93 \\
\hline 6. & Alaikal Azizir Rohman & 80 & 83 & 88 \\
\hline 7. & Akmal Zasfan Rabnan Diaz & 60 & 69 & 93 \\
\hline 8. & Alvia Wardah & 70 & 83 & 100 \\
\hline 9. & Aprilia Linnisa'i Soleha & 80 & 100 & 100 \\
\hline 10. & Boy Akill Ramadhani & 60 & 93 & 100 \\
\hline 11. & Didik Komah Setiawan & 90 & 80 & 93 \\
\hline 12. & Dhealita Inasya Zahrani & 90 & 96 & 100 \\
\hline 13. & Djenny Fariesa Putri P & 80 & 63 & 93 \\
\hline 14. & Dwi Anggun Ramadhani & 55 & 79 & 91 \\
\hline 15. & Eka Rahma Mailani & 90 & 79 & 86 \\
\hline 16. & Holikin & 55 & 69 & 89 \\
\hline 17. & Hubbiba Royhatul Imaniya & 75 & 72 & 93 \\
\hline 18. & Laila Fajrina Falah & 90 & 86 & 90 \\
\hline 19. & Mahmada Hasanatun Fillah & 55 & 83 & 95 \\
\hline 20. & Mochammad Syahril M & 80 & 74 & 91 \\
\hline 21 & Muhammad Fahad Abbas A & 70 & 76 & 97 \\
\hline 22 & Najwa Silfira Salsabilah & 60 & 89 & 88 \\
\hline 23 & Niko Surya Pradana & 90 & 69 & 93 \\
\hline 24 & Putri Maharani & 65 & 85 & 93 \\
\hline 25 & Syafira Eka Imelia & 50 & 87 & 91 \\
\hline 26 & Wadhi'atul Hudaivah & 90 & 80 & 93 \\
\hline 27 & Zazkia Anki Meilani & 90 & 79 & 96 \\
\hline 28 & Nurhayati & 55 & 82 & 91 \\
\hline 29 & Abdul Qodir & 55 & 79 & 93 \\
\hline 30 & Bagas Oktavianus & 50 & 76 & 100 \\
\hline \hline & \multicolumn{1}{|c|}{ Jumlah skor } & 2125 & 2359 & 2788 \\
\hline & Persentase (\%) & 71 & 79 & 93 \\
\hline & Kriteria Keberhasilan & C & B & A \\
\hline & & & & \\
\hline
\end{tabular}

Tabel tersebut menunjukkan perbandingan rata-rata penilaian hasil pada pratindakan, siklus I, dan siklus II. Pada pratindakan menunjukkan sebanyak 16 (52\%) siswa tuntas belajar dan 14 (48\%) siswa belum tuntas belajar. Setelah dilakukan penelitian menggunakan model KEBERSTRU dengan materi Sistem Pemerintahan Pusat pada siklus I meningkatkan hasil belajar siswa sebanyak 26 
(87\%) telah tuntas belajar dan 4 (13\%) siswa belum tuntas belajar. Sedangkan pada siklus II hasil belajar siswa meningkat sebanyak 30 (100\%) telah tuntas belajar. Peningkatan hasil belajar siswa setelah menggunakan model KEBERSTRU dipengaruhi oleh keaktifan dan kerjasama siswa yang baik selama pembelajaran serta kemampuan siswa dalam memahami materi Politik Luar Negeri Indonesia.

\section{Kesimpulan dan Saran}

Berdasarkan paparan data dan pembahasan dapat disimpulkan sebagai berikut bahwa penerapan model KEBERSTRU pada materi Politik Luar Negeri Indonesia pada kelas VI di SD Negeri Bantaran I kabupaten Probolinggo telah dilaksanakan dengan baik sesuai dengan langkah-langkah yang ada. Hal ini dapat dibuktikan dari hasil aktivitas guru dalam mengajar pada siklus I pertemuan I mencapai 84\%, pertemuan II mencapai 90\%, siklus II pertemuan I mencapai 100 $\%$, dan pertemuan II mencapai 100\%. Model KEBERSTRU dapat meningkatkan hasil belajar Politik Luar Negeri Indonesia pada siswa kelas VI di SD Negeri Bantaran I kabupaten Probolinggo. Peningkatan hasil belajar siswa dibuktikan dengan peningkatan persentase ketuntasan yang dicapai siswa. Persentase ketuntasan hasil belajar yang diperoleh siswa pada siklus I pertemuan I mencapai 76,04\%, pertemuan II mencapai 78,63\%, siklus II pertemuan I mencapai 90,30\%, dan pertemuan II mencapai 92,93\%.

Berdasarkan kesimpulan dari pembelajaran Politik Luar Negeri Indonesia melalui model KEBERSTRU pada siswa kelas VI di SD Negeri Bantaran I kabupaten Probolinggo, maka peneliti memberikan saran bagi guru, dapat menerapkan model KEBERSTRU sebagai salah satu solusi atau alternatif bahan pertimbangan dalam perbaikan dan peningkatan kualitas pembelajaran dan hasil belajar Pendidikan Kewarganegaraan. Bagi siswa, lebih bersungguh-sungguh dalam mengikuti proses pembelajaran khususnya pada mata pelajaran Pendidikan Kewarganegaraan dan harus terus dipupuk sikap kerjasama antar siswa. Bagi sekolah, dapat dijadikan sebagai masukan bagi pimpinan lembaga atau kepala sekolah untuk meningkatkan kualitas pembelajaran dan mutu lulusan siswa. 


\section{DAFTAR RUJUKAN}

Adnan, Warsito. 2012. Pendidikan Kewarganegaraanuntuk Kelas VI SD/MI. Solo: Global PT Tiga Serangkai Pustaka Mandiri.

Arikunto, Suharsimi. 2005. Prosedur Penelitian. Jakarta: Rineka Cipta.

Aziz, Abdul W. 2009. Metode dan Model-Model Mengajar IPS. Bandung: Alfabeta.

Budiyanto. 2004. Pengertian Model Pembelajaran. (Online), dalam (http://belajarpsikologi.com/pengertian-model-pembelajaran/), diakses tanggal 10 November 2014.

Dimyati dan Mudjiono. 2006. Belajar dan Pembelajaran. Jakarta: Rineka Cipta.

Gultom. 2004. Penerapan Model Pembelajaran Kooperatif Tipe Numbered Heads Together (NHT) untuk Meniingkatkan Hasil Belajar Siswa. (Online), dalam (http://www.tuanguru.com/2011/12/pembelajaran-kooperatif-tipenht.html), diakses tanggal 10 November 2014.

Nur, Mohamad. 2005. Pembelajaran Kooperatif. Surabaya: Pusat Sains dan Matematika Sekolah UNESA.

Nurhadi, dkk. 2004. Pembelajaran Kontekstual dan Penerapannya dalam KBK. Malang: Universitas Negeri Malang (UMPRESS).

Sudjana. 2005. Pengertian Penilaian Hasil Belajar. (Online), dalam (http://www.m-edukasi.web.id/2013/08/pengertian-penilaian-hasilbelajar.html), diakses tanggal 10 November 2014.

Sugiyono. 2010. Metode Penelitian Kuantitatif Kualitatif dan $R \& D$. Bandung: Alfabeta.

Yamin, Martinis. 2003. Strategi Pembelajaran Berbasis Kompetensi. Jakarta: Gaung Persada.

Zainuddin, M. 2012. Membentuk Karakter Anak Bangsa. Malang: UM Press 